\title{
The issue of intrapreneurship development in corporations
}

\author{
Teresa Piecuch \\ Department of Management, \\ Rzeszow University of Technology, \\ Poland \\ tpiecuch@prz.cedu.pl \\ ORCID 0000-0003-2656-662X \\ Elżbieta Szczygieł \\ Institute of Law and Economics, \\ Pedagogical University of Krakow, \\ Poland \\ elzbieta.sqczygiel@,up.krakow.pl \\ ORCID 0000-0002-8804-1071
}

\begin{abstract}
Due to the role corporations play in modern world, they are becoming an interesting area for theoretical considerations and a research object. The subject of the paper is intrapreneurship, which is a form of corporate entrepreneurship that refers to the individual behaviour of corporate employees. The main goal of the research was to analyse and evaluate the entrepreneurial potential of corporate employees and the working climate that affect significantly the development of intrapreneurship. The article is based on the author's research, which was conducted by means of a survey among 320 employees and 60 executives at different levels taken on in 41 different types of corporations conducting business activity in Poland. By entering the research, it was assumed that the corporation was entrepreneurial if it employs entrepreneurial employees, and its working climate is conducive to undertaking entrepreneurial initiatives. The research showed the importance of the work climate for the development of intrapreneurship, which can be considered a dimension supporting the development of corporate entrepreneurship. It was also featured that not those employees who had intrapreneur potential were more involved in risky ventures, but those who felt that the company supported their actions.
\end{abstract}

Keywords: corporate entrepreneurship, intrapreneurship, individual behaviours

JEL Classification: D22, G91, L26 


\section{INTRODUCTION}

Big corporations are very important, and their influence on shaping global economic life in the past and now is significant (Kowalska, 2013; 2019). Transnational corporations, which have the characteristics of national economies, play a special role as they are indicated as key actors in the globalization process (the foundation of the world economy), which create economic reality, set trends, contribute to the dissemination of new technologies, drive economic growth and development (Pirhadi \& Feyzbakhsh, 2021; Luo et al., 2019).

Entrepreneurship is perceived as a very important (even fundamental) factor for the development of various sizes of enterprises as a chance for higher efficiency and a better position in the market (Huarng \& Yu, 2021; Smékalová et al., 2014). It is a key resource, a serious asset in the fight against competition even in very difficult environmental conditions. Each enterprise, regardless of size, which wants to meet various challenges, should have a way of behaving in a competitive environment "steeped in entrepreneurial spirit" (Piecuch, 2018; González-López et al., 2021). This also applies to corporations which are usually very large, extensive enterprises where it is very difficult to provide working atmosphere that supports entrepreneurial behaviour (Chen et al., 2020; Belas et al., 2020). The paper draws attention to the importance of executive employees' predispositions and work climate in the development of intrapreneurship, which is a type of corporate entrepreneurship related to the individual level, to entrepreneurial behaviour implemented by executive employees. Corporate entrepreneurship is introduced at the organizational level by corporate management.

Corporate entrepreneurship and intrapreneurship are relatively new, insufficiently understood research areas, still developing and creating new, interesting, worth theoretical analysis and empirical research threads. The current research on corporate entrepreneurship largely focuses on the organizational level, which is much better recognized. They most often refer to the issues of top-down implementation of innovative projects (Badiou, Segarna-Cipres \& Escarig-Tena, 2020). They are mainly quantitative and they refer, for example, to the entrepreneurial orientation of corporations (many of them analyse the impact of entrepreneurship on enterprise performance, efficiency, innovation, competitiveness, etc. - see: Rauch, Wiklund, Lumpkin \& Frese, 2009; Wójcik-Karpacz, 2016; Belas et al., 2018). Bratnicki, Kulikowska-Pawlak, 2011; Dyduch, 2008), to the intensity of entrepreneurship (see: Morris \& Sexton, 1996; Erasmus \& Schepeers, 2008; Anor Salim, Maidin, Mhd Sarif \& Zainudin, 2019; Dyduch, 2008). Although it is generally recognized that employees are a key resource for enterprises, the literature relating to the development of entrepreneurship at the individual level is very fragmented and there are no measuring instruments. Much less research concerns the intra-community potential of executive employers. This level is underestimated and often even overlooked (De Jong \& Wennekers, 2008; Kuratko, Montagno \& Hornsby, 1990; Antoncic \& Hisrich, 2003; Badiou, Segarna-Cipres \& Escarig-Tena, 2020; Gawke, Gorgievski \& Bakker, 2019; Sharma $\&$ Chrisman, 1999; Blanka, 2019). In the literature on the subject, no research was found that would combine the individual and organizational level in the dimension proposed by the authors of the paper, which would refer to the mutual interaction between these areas. This was pointed out by, for example, P. Sharma and J. J. Chrisman, who believed that the individual (personal) level of corporate entrepreneurship was undervalued even neglected in the literature (Sharma, Chrisman, 1999). This means that there is a specific research gap that was revealed and that tried to be completed in the following areas by a critical analysis of the literature on the subject and completed studies in the field of: (1) entrepreneurial predispositions of corporate employees; (2) work climate created by corporate management and felt by employees, which is the result of management's attitude to entrepreneurial initiatives of its subordinates; (3) the impact of the above aspects on the development of corporate entrepreneurship. 
The subject of the study, theoretical considerations and conducted research is intrapreneurship (understood as entrepreneurial activities carried out by corporate employees - individual level) as well as corporate entrepreneurship (referring to corporate management - organizational level). The research was based on a survey among 41 corporations running business in Poland. As part of them, 320 executive employees and 60 executives of various levels were surveyed. The research covered two related areas: (1) analysis of the entrepreneurial potential of corporate employees; (2) assessment of the working climate in terms of the possibilities for corporate employees to take entrepreneurial actions; this was done based on the opinions of both employees and managers, who mutually contribute to creating and maintaining the work climate (a questionnaire and interviews were used for this purpose, thanks to which information was obtained from 320 employees and 60 managers of various levels).

The article contributes to the understanding of the combination of the above-mentioned aspects, is important at an individual level, and in the development of intrapreneur behaviour of corporate employees. Critical analysis of the literature on the subject related to the examined aspects and the conclusions resulting from the research (answers to the formulated research questions), recommendations, and suggestions for further research, are the detailed subject of the considerations.

\section{LITERATURE REVIEW}

Corporations are difficult work environment for the people employed in them, but also in terms of opportunities to develop entrepreneurship in them. On the one hand, creativity is required from employees, on the other one - their behaviour is never completely free, independent, they need to be associated with certain restrictions as they are implemented in the structures of a large enterprise (see. i.e. Basinska \& Rozkwitalska, 2020; Prexl, 2019; Miller-Stevens et al., 2018). The activity of an entrepreneurial employee in a corporation is, therefore, a constant balance between creativity and the need to follow rules; between entrepreneurship and an idea of limited autonomy. On the basis of these doubts, the concepts of corporate entrepreneurship and intrapreneurship were born (Peterson \& Berger, 1971). Both aim to develop entrepreneurial behaviour in corporations. Initially, these terms were used interchangeably, and with time significant differences started being pointed out. Today, corporate entrepreneurship - generally speaking is related to the organizational level of a corporation, to entrepreneurial behaviour implemented by management at various levels (Kuratko et al., 1990; Orlova \& Ovander, 2019; Pinchot, 1985; 1987; Pinchot \& Pinchot, 2016). It can be defined as a process thanks to which large enterprises aim to promote entrepreneurship among managers and other employees (Barrow, 1993). It is a process where corporations engage in diversifying their activities through internal development; that requires a combination of resources to expand existing activities in those areas that create new opportunities (Burgelman, 1983). It may consist in creating an internal environment conducive to undertaking entrepreneurial activities within the already existing corporation (Morris, Kuratko \& Covin, 2008). It contributes to the improvement of existing organizations by rationalizing activities, changing the organizational structure and management method (Wiatrak, 2008). In contrast, intrapreneurship is entrepreneurship implemented at the individual level by executive employees. It draws attention to "...ways of stimulating creativity and emotions among employees that are associated with entrepreneurship within the enterprise while providing more resources and less risk" (Corbett, 2019). It is a specific type of corporate entrepreneurship.

Intraprepreneurship is historically the oldest term used to describe entrepreneurial behaviour taken in extended enterprises (Parker, 2011). This phenomenon refers to the practices already taken in the 1940s to develop creative teams in large corporations responsible for introducing innovations and increasing the attractiveness of new products. Task teams working on introducing innovations and improving products and implemented processes were created from among the people employed in the corporation. Their role 
boiled down to making the offered products more attractive and, consequently, to improve the position of the corporation in the market compared to competitors (Caraland \& Caraland, 2007; Anu, 2007; Matusiak, 2011, Aina \& Solikin, 2020). People who form creative teams are intrapreneurs whose "discovery" - as G. Pinchot emphasized - filled the missing link of entrepreneurial activities implemented in large enterprises (Pinchot, 1987). The development of entrepreneurship in corporations depends mainly on them (with considerable participation of the management).

According to Pinchot and Pinchot (2016), intrapreneurship is a peculiar style of action (opposed to the bureaucratic style), which is characterized by dynamism, flexibility, and orientation towards implementing innovations. It is a set of good business practices that gives employees with an entrepreneurial personality an opportunity to quickly implement innovations in large enterprises (Cadar \& Badulescu, 2015; Azami, 2013). This is the first link (the lowest level) of corporate entrepreneurship (Piecuch, 2018). It includes bottom-up initiatives of employees influencing the entrepreneurial orientation of the entire corporation (Nessen, Caniels \& de Jong, 2019). It means doing new things, going beyond traditional methods, looking for previously unknown possibilities of action. It is a process where active (often even aggressive, rebellious) units within a large enterprise implement innovative undertakings contributing to strategic renewal (Gawke, Gorgievski \& Bakker, 2019). As a consequence, it means encouraging them to implement new ideas, which directly translates into the number of generated and innovative solutions implemented in corporations (Brigić \& Alibegović, 2019).

Therefore, the potential of employees, being the "first link" of corporate entrepreneurship, is necessary for the development of entrepreneurship in a corporation. The basic resource, the main "actors" of the process are entrepreneurial corporation employees - intrapreneurs - people who are very active, full of passion and commitment, not afraid of taking unconventional, even very risky actions (Cieślik, 2014), which are the engine of growth and development of the corporation (Bosma, Stam \& Wennekers, 2011). These are internal entrepreneurs operating at the individual level, who, thanks to the conditions created by the corporate entrepreneurs operating at the organizational level (Blanka, 2019), create innovative solutions (Piecuch, 2018). Their positive attitude to reality, to emerging problems affect individual, team and, consequently, entire corporations.

Work climate, in which the creative potential of employees has a chance to be revealed and fully develop, plays an important role while taking up the risk of engaging in the implementation of innovative projects by employees. It includes, among others: a sense of autonomy, support from management and workmates, as well as confidence in undertaken activities. "Such the climate reflects the interaction between the organizational situation, group members and culture. It shows the unique individual insights of organizational reality, while individual consciousness is verified. That is why the climate should be the focal point of the description of the organization as a system of meanings and symbolic action" (Nawrat, 2013).

Climate is the dimension that employees "feel" (although the employee is not only a "recipient" but also a "co-creator" of the climate - Nawrat, 2013), and this perception is manifested in specific attitudes, behaviours, expressed and felt emotions. It can be identified (also measured) based on the perception of employees (revealed in their subjective feelings) about the working conditions prevailing in the company, and the relations between supervisors and employees (Piecuch, 2018). An atmosphere conducive to entrepreneurship means climate of creative anxiety, where striving for improvement, intolerance to mediocrity, but also forbearance and tolerance of mistakes and risk should be important values. In such conditions employees do not think about how to solve a given problem, but rather how to do it in an unusual, innovative way. It is the climate of innovation (climate of creativity - see: Nawrat, 2013) - employees are expected to be creative and original in finding new and better ways of doing work. It is possible to achieve thanks to the right approach to employees, the use of leadership styles focused on people, 
cooperation and collaboration. The climate of innovation allows taking risks, experimenting, questioning of the existing ways of solving problems.

Employees will not get involved and take risks in enterprises where "...there is a tendency to intensified resistance against everything new, usually expressed in the generation of false assessments, gossip, accent and exaggeration of the flaws and imperfections of the proposed solutions, silence of advantages or hostility in relation to people who propose "new rules of the game" usually requiring more effort and break with existing habits "(Jasiński, 2004). Therefore, an atmosphere of trust, focused on cooperation and creating partner relationships, is of great importance. It is characterized by curiosity, mutual sympathy, a sense of group community, support, striving to develop and improve ideas presented by others. It gives a sense of security as employees know that their failures will not be criticized, they do not have to fear penalties or lose their jobs in the event of failure. Thanks to this, it is possible to obtain creative energy, commitment, high productivity and efficiency of people participating in the work of the group. High-quality relationships between people, positive moods at work, support from colleagues, internal management policy towards employees steeped in the spirit of entrepreneurship, focused on subjective entrepreneurship affect greater involvement in entrepreneurial activities - resulting in the implementation of innovative solutions (He \& Hui, 2020; Tseng \& Tseng 2019).

\section{METHODOLOGY}

In order to discover the real situation of the corporations in terms of the possibilities of intrapreneurship development in them, empirical research was carried out using the survey technique, which applied a standardized and categorized questionnaire as a research tool. It contained questions about the intrapreneurial potential of corporate employees and the working climate. In case of the intrapreneurial potential of corporate employees, for this purpose a test developed by Pinchot (1985) was used. The intrapreneurial potential has been possessed in the case of a person who answered more than $50 \%$ of the questions in the affirmative way. The more the number of affirmative answers approaches the maximum, the greater, the intrapreneurial potential inherent in a given employee (Pinchot, 1985). In case of the working climate in the scope of the possibility for corporate employees to undertake entrepreneurial activities, a proprietary set of formulas was used, describing, among others, the management approach to employee entrepreneurial initiatives, risk taking, experimentation, etc.

Interviews conducted only with corporate employees in managerial positions were the supportive method used in the research. 10 individual interviews based on questionnaires were carried out, although additional questions were also asked. They allowed learning about the specifics of work in corporations, their relationships, also the terminology used, specific markings, abbreviations, etc. Thanks to this, it was possible to supplement the knowledge of the research implementer on interesting issues. This contributed to a better understanding of the phenomenon, the complexity of conditions (including connections, relationships, interactions) taking place in corporations and affecting the development of entrepreneurship in them (or limiting its development). These conversations were directed, although their course depended to a large extent on the respondent and included a large margin of freedom. The nature and duration of them depended on the personality of managers, the resources of their knowledge, because they often deepened the topics discussed themselves, "...saturated them with contexts resulting from their previous professional experience" (Moroz, 2013), which had a very positive impact on the number and quality of information obtained.

Due to the fact that the examined aspects are of a qualitative nature and that the group was not very numerous, the hypotheses were abandoned in favour of research questions. The desire to verify (or falsify) hypotheses in this case could raise problems and doubts. The answers to research questions (similarly to the 
verification of hypotheses) allow performing research task, and achieving research objectives (Moroz, 2013; Ciesielski, 2011). For the purposes of the research, the following research questions were formulated: Do employees taken on in corporations have entrepreneurial potential? Is the corporate climate conducive to entrepreneurial behaviour?

Within the research, it was assumed that the entrepreneurial corporation employs intrapreneurial employees, and the prevailing climate work favours the implementation of entrepreneurial initiatives.

The research referred to the entrepreneurial predisposition of corporate employees and the working climate, therefore the study covered 320 employees, 60 managers taken on in 41 large enterprises of various industries operating in Poland. They were selected in a deliberately, but also based on the criterion of availability and willingness to participate in the research. The author depended on the diversity of the studied sample. The study covered large and very large enterprises (including executive employees and managers of various levels), which were selected using a deliberate selection (also guided by the principle of availability). The study covered commercial enterprises whose representatives expressed their willingness to take part in the research (in the first place, it was a manager of one of the intermediate management levels, which depended on the organizational structure of the corporation, who agreed to the research, and then commissioned a group of his subordinates to complete the surveys). These were the large enterprises meeting the criterion of size measured by the number of employees (thus employing at least 250 employees), with separation of ownership from management, with a group of paid non-owner managers actively involved in management, with at least one intermediate management level.

The analyses were based on numerical statements with using of the ANOVA Kruskal Wallis test and the Pearson's $\mathrm{Chi}^{2}$ test of independence. The test allow to assess the statistic significance of the differences between the selected features. The research was carried out at the significance level $\alpha=0.05$. For analysis of relation between variables, the Spearman's rank correlation was applied to check for the occurrence of statistical significance $(\mathrm{p}<0.05)$. In the analysis approve, when $\mathrm{p}<0.05$ - statistical significance; $\mathrm{p}<0.01$ high statistical significance; $\mathrm{p}<0.001$ - very high statistical significance.

Due to the size of the research sample, the conducted research is not representative, therefore the formulated conclusions cannot be generalized to all corporations - they refer only to the surveyed entities.

\section{EMPIRICAL RESULTS}

When characterizing the surveyed corporations, taking into account their dominant features, it can be concluded that most of them were production enterprises operating on the basis of functional structure, with a long period of functioning in the market - over 21 years, with an international range of activity. The entrepreneurial potential of 320 employees was analysed in the corporations. They also evaluated the work atmosphere. Most of them were young men, with higher education, with short work experience - up to 5 years. The surveyed employees of the corporation represented a total of 82 different professions (in the version in which the respondents gave it, without grouping them into categories; the answers to this question were very dispersed, which is, however, specific for open-ended questions), most often they were: customer advisor, manual worker, fitter, constructor, logistics, mechanic, electrician, lab technician, operator of various types of machines, locksmith and many others. The surveyed managers are mostly men aged 31-40 with higher education.

\subsection{Potential of entrepreneurship}

Based on the research, it can be concluded that in the studied group of 320 employees of the corporation, the low $(36 \%)$ and medium $(32 \%)$ potential of intrapreneurship predominated. Relatively many of them $(21 \%)$ could not be assessed as entrepreneurial, and only $11 \%$ were real intrapreneurs - people with 
high entrepreneurial potential. By analysing in detail the responses, it can be stated that the greatest support $(80 \%$ and more responses) was obtained by three statements related to the assessment of entrepreneurial potential (table 1).

Table 1

Respondents' assessment of entrepreneurship's potential

\begin{tabular}{|l|c|}
\hline \multicolumn{1}{|c|}{ The content of the question } & $\begin{array}{c}\text { Yes } \\
(\%)\end{array}$ \\
\hline $\begin{array}{l}\text { Do you have (do you use) a network of relationships with colleagues that you can always count on? } \\
\text { Are you annoyed by people trying to incompetently use elements of your idea? }\end{array}$ & 89 \\
\hline Can you imagine the specific steps to take as you consider ways to make your idea come true? & 81 \\
\hline Are you excited about your work? & 68 \\
\hline $\begin{array}{l}\text { Can you keep your ideas secret and refrain from sharing them until you can test them and make an } \\
\text { implementation plan? }\end{array}$ & 66 \\
\hline $\begin{array}{l}\text { Are you considering the possibility of giving up your natural perfectionism, making you do everything } \\
\text { yourself and sharing the responsibility for implementation with your team? }\end{array}$ & 63 \\
\hline Have you been going through difficult times when the project you were working on seemed impossible? & 63 \\
\hline Do you think about new business ideas also outside of work, e.g. driving to work, relaxing? & 59 \\
\hline Do you risk trouble from time to time by doing things that exceed your assigned competencies? & 54 \\
\hline $\begin{array}{l}\text { Would you be willing to forgot a portion of your salary in order to have a chance to implement the idea if } \\
\text { the reward, if it were successful, was adequate? }\end{array}$ & 47 \\
\hline $\begin{array}{l}\text { Does your work take as much time (or more) to improve the status quo as it does to fulfill your standard } \\
\text { responsibilities? }\end{array}$ & 44 \\
\hline
\end{tabular}

Source: Own study based on the research.

In their workplaces, the employees of the corporations had and maintained networks of relations with their colleagues, they could always count on their help and support - this obtained the most, up to $89 \%$ of affirmative answers among all the statements used in the research. This confirms the information contained in the literature on the subject, where it is emphasized that an intrapreneur cannot (and should not even) act alone. In the corporation "... no individual, no matter how brilliant it would be, will not lead a breakthrough innovation through the entire process - from idea to implementation; innovation must be a company-wide process, top-down supported by systems, structures, culture that support transformed ideas and products" (Corbett, 2018).

The employees knew what they were doing, were able to imagine the steps to be taken to implement a given idea, solve a problem (81\% of responses). This is undoubtedly a potential that they could also use in creative work. Being aware of the essence of the problem, its components, it is easier to make a creative combination of resources available at a given time to create something better.

The employees reacted negatively to people trying to use elements of their ideas in an incompetent way (81\% of responses). This shows their commitment to what they did, that they cared about what was happening to their idea, that they were confident in their knowledge by considering (and being able to assess) the actions of others as inept. This question also indicates the problems often encountered in corporations with the implementation of projects by their authors. Corporations are huge, complicated, conglomerates achieving the goals of many diverse stakeholders, which is not necessarily coincident with the interests of the authors of innovative solutions.

Only two questions included in the questionnaire for the assessment of intrapreneurial potential obtained fewer than 50\% of responses: the time employees spent on standard duties and creative work and remuneration, from which part of the employees would be able to give up, to have a chance to implement the idea. The studies showed that routine activities required more involvement. Respondents devoted significantly less time to creative work and this statement received the least support among all the questions (44\%). In case of remuneration, from 
which part of the employees would be able to give up, to have a chance to implement the idea, if the prize in the event of its success would be adequate, most of the respondents would not agree to sacrifice part of their remuneration in the name of implementing innovative, therefore risky ideas. Only $47 \%$ of respondents agreed for this. This raises the question about the level of wages, which was probably not high, hence the distribution of answers. Another reason could be the low efficiency of implementing innovative solutions in the studied corporations, the employees' lack of faith in the positive ending of implemented projects, and often very large time shifts between the idea and possible gratuities, which may discourage.

By comparing the questions contained in the G. Pinchot test with the data of the record, a number of very interesting conclusions were obtained. For example, it turned out that a very highly statistically significant correlation $(\mathrm{p}<\alpha, \mathrm{p}=0.000096)$ occurred between whether employees of corporations thought about on-going projects also outside work, and their age. The studies showed that young people were the most committed to work, they analysed the ideas they also worked on in their free time, they were completely involved in what they did. Similarly (though to a slightly lesser extent), this question depended on seniority $(p<\alpha, p=0.0339)$. This confirms the information about the specifics of work in corporations. They show that they prefer to employ young, very creative people, even with shorter work experience, but who are available and involved (often without restrictions) in the tasks entrusted to them.

The most statistically significant correlations in the questions of the G. Pinchot test relating to the entrepreneurial potential of corporate employees were revealed in the case of education which had the impact on whether the employees were excited about their work $(\mathrm{p}<\alpha, \mathrm{p}=0.01314)$. They thought about new business ideas implemented at work outside of it, even in free chat $(p<\alpha, p=0.0025)$ - this relationship turned out to be highly statistically significant. The employees were able to imagine specific steps to be taken when considering different ways of implementing an idea $(p<\alpha, p=0.02491)$, as well as they were even able to expose themselves to problems in the process of implementing ideas, taking actions that exceeded their competences, went beyond routine, standard actions $(p<\alpha, p=0.01508)$. The employees would be willing to give up part of their remuneration to increase their chances of realizing their idea if the prize in the event of success would be adequate to the value of the prize (bonus) achieved as a result of implementing their solution $(\mathrm{p}<\alpha, \mathrm{p}=0.02181)$.

The relationships mentioned above were quite interesting because it turned out that employees with higher education were the most excited about work, then vocational, least with medium. To the question "Can you imagine the next steps to be taken while implementing the project?", more often, employees with higher education followed by vocational. The least favourable in this aspect are (once again) employees with secondary education. Studies showed that higher education, therefore (probably) higher knowledge, facilitated work on the project, such employees were much more substantively prepared for the implementation of new ideas. On the other hand, vocational education also gives - as it turned out - practical knowledge relevant to implementing innovative solutions. Analysing the answers to the question about whether employees think about new business projects also outside work, it turned out that this relationship increased with a growth of education. Therefore - the higher the education of employees - the more often they thought about implemented projects also in their free time, although the difference between vocational and secondary education turned out to be small.

\subsection{Climate of work}

The analysis and assessment of the working climate in the analysed corporations were other important stages of the research. An original set of 12 formulations was used for this purpose. The reliability coefficient of the Cronbach's Alfa coefficient measurement calculated for the questionnaire reached a high level (0.87), which indicates that the respondents' answers were consistent and logical, and the questions used were well 
selected. The positions of the respondents relating to the expressions used to assess the working climate are included in table 2 . The respondents best ( $80 \%$ of affirmative answers) rated the relationships prevailing in their teams, both among employees as well as between employees and management. This probably resulted in the fact that they felt good and safe at their workplace ( $77 \%$ of affirmative answers). They also claimed that the ideas they proposed were supported by superiors $(71 \%)$, who encouraged them to be creative, active and to formulate new solutions $(70 \%)$, and as a consequence employees were not afraid of negative evaluation or critical comments from management $(70 \%)$.

Table 2

Respondents' assessment of work climate in corporations

\begin{tabular}{|l|l|c|}
\hline \multicolumn{1}{|c|}{ The content of the question } & Yes (\%) & No (\%) \\
\hline Employees feel good and safe in the company. & 77 & 23 \\
\hline Ideas proposed by employees are supported by management. & 71 & 29 \\
\hline Supervisors encourage employees to formulate their own ideas. & 70 & 30 \\
\hline Employees are not afraid to present their ideas, they are not afraid of negative evaluation. & 70 & 30 \\
\hline Employees are praised and rewarded for new ideas (for creativity). & 46 & 54 \\
\hline Employees are punished for mistakes and wrong solutions. & 45 & 55 \\
\hline Employees are not afraid to take risks. & 64 & 36 \\
\hline Employees who have ideas and want to implement them are free to implement them. & 58 & 42 \\
\hline Creative employees are supported in the enterprise. & 67 & 33 \\
\hline Employees are satisfied with contacts with colleagues and management. & 80 & 20 \\
\hline The management ensures friendly relations among employees. & 75 & 25 \\
\hline The interested employees are trained to look for unconventional solutions. & 56 & 44 \\
\hline
\end{tabular}

Source: Own study based on the research.

The respondents' answers to two questions turned out to be interesting and controversial - one concerned punishment for mistakes (45\% of affirmative answers), the other - praising and rewarding employees for their work progress, and creativity $(46 \%)$. It turns out that in the corporations surveyed, they were rarely punished for mistakes, but on the other hand they were not praised and rewarded for good results. In the literature, punishment for mistakes is considered one of the most important barriers preventing the development of intrapreneurship (Eesley \& Longenecker, 2006). It kills any activity and commitment now and in the future. On the other hand, the lack of penalties is not enough - it should be supported by appropriate motivation, and one of its types is positive support, rewarding and praising for work progress. This, however, was lacking in the corporations surveyed.

For more accurate analysis of the statements used to assess the entrepreneurial working climate, the Spearman's rank correlation was applied to check for the occurrence of statistically significant relationships between them (for $\mathrm{p}<0.05$ ). The analysis shows that the vast majority of correlations were statistically significant. Most often these were average correlations, ranging from 0.3 to 0.5 . Considering the strongest (with a compound strength of 0.5 to 0.7 ), it can be stated that the better relations management creates among employees, the more they are satisfied with contacts with their colleagues. Similarly, the more managers encourage their subordinates to formulate new ideas, the more they are then supported by management (e.g. in the process of their implementation). The relationship was also in the case of the more employees felt good and safe in their company, the more willing they were to take risks. Similarly, the more managers encourage their subordinates to formulate their own ideas, the more employees are not afraid to present new ideas, are not afraid of negative assessment, criticism, ridicule, etc. 
The Pearson's Chi ${ }^{2}$ test of independence was also used to analyse the working climate. On this basis, it was demonstrated, for example, that education was statistically significant, which was related to the following four statements:

- new ideas proposed by employees are supported ( $\mathrm{p}<\alpha, \mathrm{p}=0.04983)$;

- employees are not afraid to present their ideas in order not to be poorly assessed ( $p<\alpha, p=0.04773$ );

- employees are praised and rewarded for new ideas $(p<\alpha, p=0.00092)$; this relationship was very highly statistically significant, it turns out that the higher the education, the more frequent the praising and rewarding;

- employees who have ideas and want to implement them are free to implement them $(\mathrm{p}<\alpha, \mathrm{p}=$ 0.00932).

The research also showed that employees were more willing to take the trouble and risk of working on new, innovative, high-risk solutions when:

- they are not afraid of negative assessment $(p<\alpha, p=0.01418)$,

- are praised and properly rewarded for their ideas $(p<\alpha, p=0.00067)$, this relationship turned out to be very highly statistically significant,

- are free to implement the solutions they propose $(\mathrm{p}<\alpha, \mathrm{p}=0.01150)$,

- feel that in their enterprise management supports active, entrepreneurial units $(p<\alpha, p=0.00259)$ this relationship turned out to be highly statistically significant,

- management ensures that there are adequate and friendly relationships between employees in the corporation $(\mathrm{p}<\alpha, \mathrm{p}=0.03429)$.

The completed research enabled the formulation of a number of conclusions, selected (due to limited volume) are presented in the next part of the study.

\section{DISCUSSION}

As mentioned above, the study presents the author's research design, which analyses employee predispositions and work climate and their impact on the development of intrapreneurship and, consequently, corporate entrepreneurship. It is therefore difficult to refer directly to the authors of other studies combining the two aspects studied. However, it is possible to identify authors who, like the study in question, have demonstrated the importance of work climate in the development of intrapreneurship (Blanka, 2019; Tastan \& Gucel, 2014; Poduska et al., 2020; Buekens, 2014). In each case, different ways of investigating it were used. They generally agree that in an intrapreneurial climate employees are not afraid of criticism, are more willing to take risks and feel supported by their colleagues. Under such conditions, even high-risk innovative ventures are more likely to be implemented in a supportive atmosphere.

In our research, the intrapreneurial potential of corporate employees was observed at a high level, as evidenced by such behaviours. The employees owned and used a network of relationships with colleagues (especially important in manufacturing corporations) and therefore, they worked in teams implementing specific projects. They were satisfied with their systems and work atmosphere, which could influence more of their innovative solutions. The employees were also personally involved in what they did and were excited about their work. They were able to value their contribution to implemented projects and did not accept a situation when someone else would like to use elements of their idea. The employees were nervous when the project they were working on turned out to be impossible. Finally, they had appropriate knowledge, were substantively prepared for what they were doing, and were able to imagine specific steps to be taken in implementing a given project. 
In the process of development of corporate entrepreneurship, in addition to employee predispositions, it is necessary to have an appropriate work environment, proper atmosphere and support for entrepreneurial behaviour. If they are more friendly, employees are more likely to get involved in their tasks, are not afraid to take risks and take the initiative. When assessing the respondents' answers regarding this aspect, it can be said that the biggest doubts are raised about the issues that significantly affect the involvement of employees in entrepreneurial initiatives. Unfortunately, in the surveyed corporations they cannot be assessed positively because, i.a. the employees were punished for mistakes and they were rarely praised and rewarded for showing initiative, for formulating new ideas - in a word - for entrepreneurship. Their ideas were not supported. The employees did not find recognition among superiors, who did not encourage (or did it to a small extent) their subordinates to take risky challenges, to experiment, and to formulate innovative solutions. They concerned did not have an opportunity to improve their qualifications at trainings on creativity, creativity. The employees wishing to implement their ideas did not obtain adequate freedom of action.

The important stage of the research was to relate the entrepreneurial potential of corporate employees and the work atmosphere to the level of corporate entrepreneurship. On this basis, it was possible to obtain the answers to the following research statements:

- entrepreneurial corporations do not employ mostly employees with entrepreneurial potential,

- the atmosphere at work in corporations has a positive effect on employees' undertaking entrepreneurial initiatives.

To sum up, it can be said that the development of entrepreneurship in corporations is possible, what's more - it is necessary for huge, transnational enterprises to be able to function normally and effectively compete with other entities in the contemporary, increasingly complicated world. Even very large corporations:

- who will appreciate the importance of entrepreneurship,

- who are able to instill in their employees an "intrapreneur spirit",

- in conjunction with the resources at their disposal,

- with the opportunities created by the global scale of operations and international partners, they are able to achieve a lot, even in very difficult environmental conditions.

The research presented in the paper is unique and worth repeating in order to at least compare the results obtained. This would be cognitively valuable especially as the subsequent research would be carried out during the period of the global COVID-19 pandemic, which changed the calculations of all companies, of all industries worldwide. It probably also influenced the working atmosphere and interpersonal relations. These issues are worth further in-depth analysis. Future research could also be enriched by looking at the role of management (the immediate supervisors of executive staff) in creating work atmosphere. A great deal depends on this group, as managers have the tools to effectively encourage initiative. They can be a support to their subordinates. On the other hand, they can also discourage, demotivate. These issues should therefore be taken into account in future research.

It is also worth noting the important limitations of the research process. Above all, it is the fact that research is carried out in corporations, which are very large, elaborate enterprises with often very complex structures. It is difficult to obtain research approval in these settings, especially as the pathway to the decision-maker can often be long and complicated. As a result, the number of corporations in which the survey was conducted was not large and the duration of the survey was very long. Now, under pandemic conditions, the situation may become even more difficult. Companies have to cope with many unknown problems, hence very often the lack of a positive attitude on their part towards research, which puts an additional burden on employees and takes time. Despite these limitations, it is worth making the effort to 
carry out the research, as it is the only way to learn about the real situation in corporations with regard to the issues analysed in the study.

\section{CONCLUSION}

Intrapreneurship is gaining more and more popularity in scientific literature, but also among entrepreneurs. It forms the basis (first level) of corporate entrepreneurship development. An in-depth knowledge and understanding of the mechanism of intrapreneurship development can be of applied importance. It can be useful for entrepreneurs supporting the development of entrepreneurship in their companies - regardless of their multiplicity, the subject of their activity. It can also be a positive stimulus, a good example for others, who do not appreciate entrepreneurship in economic processes, do not see its impact on innovation, effectiveness, competitiveness.

The article provides a systematic review of the definitions of corporate intrapreneurship. The factors influencing their development were presented. Special attention was paid to the work climate and entrepreneurial predispositions of employees. It was assumed that entrepreneurial corporations employ workers with entrepreneurial predispositions, and that their working climate is conducive to experimentation and initiative. The available literature on the aspects discussed was mainly focus on the determinants of corporate entrepreneurship development, at the organisational level. Only a few authors characterise them taking into account the individual level relating to the intrapreneurial potential of corporate employees. The scientific considerations included in the study, also the independent research of the authors combines these two levels It is unique, because there is no similar research in the literature on the subject. Thus, they provide very useful in business practice knowledge on the determinants of corporate entrepreneurship development and the role of intrapreneurial predispositions of employees in this process. Research has shown that a great deal depends on the right working atmosphere. Corporations that appreciate this dimension can count on the realisation and implementation of entrepreneurial, innovative projects.

\section{REFERENCES}

Aina, Q., Solikin, I. (2020). Entrepreneurship and intrapreneurshop: how supporting corporate performance. Review of Integrative Business \& Economics Research, 19 (1), 288-298.

Anor Salim, F., Maidin, A., Mhd Sarif, S., \& Zainudin, D. (2019). The developing entrepreneurship training curriculum based on Tawhidic paradigm and legal principles: A case study of Malaysia. Economics, Management and Sustainability, 4(2), 30-39. doi:10.14254/jems.2019.4-2.3

Antoncic, B., Hisrich, R. D. (2003). Clarifying the intrapreneurship concept. Journal of Small Business Enterprise Development, 10 (1), 7-24. doi: 10.1108/14626000310461187.

Anu, L. (2007). Fostering intrapreneurship - the new comparative edge. Conference on Global Competition and Competitiveness of Indian Corporate. Downloaded from: dspace.iimk.ac.in/bitstream/2259/471/1/149-156+.pdf

Azami, S. (2013). Intrapreneurship - “An Exigent Employment”. International Journal of Scientific \& Technology Research 2(4), 194-198.

Badiou, G. A., Segarna-Cipres, M., Escrig-Tena, A. B. (2020). Understunding employees' intrapreneurial behavior: a case study. Personnel Review, 49 (48), 1677-1694. doi: 10.1108/PR-04-2019-0201

Basinska, B.A., Rozkwitalska, M. (2020). Psychological capital and happiness at work: The mediating role of employee thriving in multinational corporations. Current Psychology. Published online : 02 January 2020. doi: 10.1007/s12144019-00598-y

Barrow, C. (1993). The Essence of Small Business. New York, Prentice Hall.

Belas, J., Amoah, J., Petráková, Z., Kliuchnikava, Y., \& Bilan, Y. (2020). Selected factors of SMEs management in the service sector. Journal of Tourism and Services, 21(11), 129-146. https://doi.org/10.29036/jots.v11i21.215. 
Belas, J., Gavurova, B., \& Toth, P. (2018). Impact of selected characteristics of SMEs on the capital structure. Journal of Business Economics and Management, 19(4), 592-608. https://doi.org/10.3846/jbem.2018.6583

Blanka, C. (2019). An individual level perspective on intrapreneurship: a review and ways forward. Review of Managerial Science, 13, 919-961. doi:10.1007/s11846-018-0277-0

Bosma, N., Stam, E., \& Wennekers S. (2011). Intrapreneurship versus independent entrepreneurship. Tjalling C. Koopmans Research Institute, Discussion Paper Series, No. 11-04, Utrecht School of Economics

Bratnicki, M. (2002). Przedsiębiorczość i przedsiebbiorcy wspótczesnych organizacji. Katowice, Wydaw. AE

Bratnicki, M., Kulikowska-Pawlak, M. (2011). Orientacja przedsiębiorcza i efektywność organizacji w kontekście strategicznych problemów rozwoju [in:] Zmiana warunkiem sukcesu. Przełamywanie barier rozwoju $i$ wærostu przedsiębiorstw. Ed. K. Skalik. Wrocław: Wydaw. UE

Brigić, M, Alibegović, S. D. (2019). Development of innovations under the impact of intrapreneurship activities in production enterprises. Ekonomski Vjesnik, 32 (2), 321-334

Brikinshaw, J. (2015). The paradox of corporate entrepreneurship. Downloaded from: http://www.strategybusiness.com/article/8276?gko $=8 \mathrm{c} 782$

Buekens, W. (2014). Fostering Intrapreneurship: The challenge for a New Game Leadership. Procedia - Economics and Finance, 16, 580-586, doi: 10.1016/S2212-5671(14)00843-0

Burgelman, R. A. (1983). A Model of the interaction of strategic behavior. Corporate context, and the concept of strategy. Academy of Management Review, 8 (1), 61-71. doi: 10.2307/257168

Cadar, O., Badulescu, D. (2015). Entrepreneur, Entrepreneurship and Intrapreneurship. A literature Review. The Annals of the University of Oradea. Economics Sciences, XXIV (2), 658-664

Carland, J. A., \& Carland, J. W. (2007). Intrapreneurship: A requisite for success. The Entrepreneurial Exceutive, 12 , 83-94.

Cieślicki, M. (2011). Model rozprawy habilitacyjnej w naukach o zarządzaniu. Pržeglad Organizacji, 10, 3-4

Cieślik, J. (2014). Przedsiębiorczość, polityka, rozwój. Warszawa: Wydaw. Akademickie SEDNO

Chen, L., Zou, S., Xu, H., Chen, Y. (2020). Entrepreneurial Orientation in Multinational Corporations: Antecedents and Effects. Management International Review, 60, 123-148. doi: 10.1007/s11575-019-00397-4

Corbett, A. (2019). Mit intraprzedsiębiorcy. Downloaded from: https://www.hbrp.pl/b/mitintraprzedsiebiorca,/P1GebPmuw

De Jong, J. P. J., Wennekers S. (2008). Intrapreneurship. Conceptualizing entrepreneurial employee behavior. Downloaded from: //ondernemerschap.panteia.nl/pdf-ez/h200802.pdf

Dyduch, W. (2008). Pomiar przedsiębiorczości organizacyjnej. Katowice: Wydaw. AE w Katowicach

Eesley, D. T., \& Longenecker, C. O. (2006). Gateways to intrapreneurship. Industrial Management, 48(1), 18-23

Erasmus P., Scheepers, R. (2008). The Relationship Between Entrepreneurial Intensity and Shareholder Value Creation. Managing Global Transitions, 6 (3), 229-256

Gawke, J. C., Gorgievski, M. J., Bakker A. B. (2019). Measuring intrapreneurship at the individual level: Development and validation of the Employee Intrapreneurship Scale (EIS). European Management Journal 37 (6), 806-817. doi: 10.1016/j.emj.2019.03.001

González-López, M.J., Pérez-López, M.C. \& Rodríguez-Ariza, L. (2021). From potential to early nascent entrepreneurship: the role of entrepreneurial competencies. International Entrepreneurship and Management Journal, 17, 1387-1417. doi: 10.1016/j.emj.2019.03.001

Guth, W. D., \& Grinsberg, A. (1990). Corporate Entrepreneurship. Strategic Management Journal, 11 (1), 5-15

He, Q., Hui, D. (2020). Organizational Intrapreneurship Policy, Entrepreneur Subjectivity, and Employees' Intrapreneurship Activity. International Journal of Information Systems in the Service Sector, 12 (1), 1-15. doi: 10.4018/IJISSS.2020010101

Hofstede G. (2000). Kultury i organizacje. Warszawa: Wydaw. Ekonomiczne

Huarng, KH., Yu, T.HK. (2021). Complexity theory of entrepreneur characteristics. International Entrepreneurship and Management Journal, 17, 1037-1048. doi: 10.1007/s11365-020-00718-2

Jasiński, Z. (2004). Uwarunkowania przedsiębiorczości. Kształtowanie środowiska dla zachowań przedsiębiorczych [in:] Kapitat ludzki a ksztattowanie przedsiębiorczości. Ed. Juchnowicz, M. Warszawa: Wyd. Poltext

Kowalska, K. (2013). Korporacje międzynarodowe w gospodarce światowej [in:] Pržemiany w gospodarce światowej: wybrane aspekty. Ed. Pach, J., Murzyn, D. Kraków: Wyd. Nauk. Uniwersytetu Pedagogicznego 
Kowalska, K. (2019). Dissemination of CSR Practices within the Framework of Cooperation Between International Corporations and Local Companies of the Host Country. Studies of the Industrial Geography Commission of the Polish Geographical Society, 32(2), 142-151. doi: 10.24917/20801653.322.9

Kuratko, D. F., Montagno, R. V., Hornsby, J. S. (1990). Developing an intrapreneurial assessment instrument for an effective corporate entrepreneurial environment. Strategic Management Journal, 11, 49-58

Luo, Y., Zhang, H. \& Bu, J. (2019). Developed country MNEs investing in developing economies: Progress and prospect. Journal of International Business Studies, 50, 633-667. doi: 10.1057/s41267-019-00230-y

Masom, E., Eghdami, A., Derakhshan, M., Ashore, S., Ghanimet, P. (2013). The Relationship between Organizational Climate Dimensions and Corporate Entrepreneurship. Research Journal of Recent Sciences, 2 (11), 107-113. doi: 10.1016/j.sbspro.2014.09.091

Matusiak, K. B. (2011). Przedsiębiorca wewnętrzny. Intraprzedsiębiorca. Stownik Innowacji-Leksykon haseł. Downloaded from: http://www.pi.gov.pl/parp/chapter_96055.asp?soid=321F89A3F42D462BB337CA5A34C108E7

Miller-Stevens, K., Taylor, J.A., Morris, J.C., Lanivich, S.E. (2018). Assessing Value Differences Between Leaders of Two Social Venture Types: Benefit Corporations and Nonprofit Organizations. VOLUNTAS: International Journal of Voluntary and Nonprofit Organizations, 29, 938-950. doi: 10.1007/s11266-017-9947-9

Moroz, M. (2013). Ksztattowanie elastyczności przedsiebiorstw internetowych. Wrocław: Wydaw. UE

Morris, M. H., Kuratko, D. F., Covin, J. G. (2008). Corporate Entrepreneurship \& Innovation. USA: Thomson Learning Inc.

Morris, M, H., Sexton, D. L. (1996). The Concept of Entrepreneurial Intensity: Implications for Company Performance. Journal of Business Research, 36 (1), 5-13. doi: 10.1016/0148-2963(95)00158-1

Nawrat, D. (2013). Wspieranie innowacyjności poprzez kształtowanie klimatu pracy. Ed. Sułkowski, Ł., Sokołowski, J. Przedsiębiorczość $i$ zarzadzanie. Lódź: Wydaw. SAN

Nessen, P. C. M., Caniels, M. C. J., de Jong J. P. (2019). The intrepreneurial employee: towar dan integrated model of intrapreneurship and research agenda. International Entrepreneurship and Management Journal, 15, 545-571. doi: $10.1007 /$ s11365-018-0552-1

Orlova, K., \& Ovander, N. (2019). Analytical support for enterprise's development management under conditions of economy digitalization. Economics, Management and Sustainability, 4(2), 21-29. doi:10.14254/jems.2019.4-2.2

Parker, S. C. (2011). Intrapreneurship or Entrepreneurship. Ournal of Business Venturing, 26 (1), 19-36, doi: 10.1016/j.jbusvent.2009.07.003

Peterson, R.A., Berger, D.G. (1971). Entrepreneurship in Organizations: Evidence from the Popular Music Industry. Administrative Science Quarterly, 16(1), 97-106. doi: 10.2307/2391293

Piecuch, T. (2018). Rozwój prždsiębiorczości korporacyjnej - perspektywa indywidualna i organizacyjna. Rzeszów: Oficyna Wydawnicza Politechniki Rzeszowskiej

Pinchot, G. (1987). Innovation Through Intrapreneuring. Research Management, $30 \quad$ (2), 14-19. doi:10.1080/00345334.1987.11757021

Pinchot, G. (1985). Intrapreneuring: Why you don't have to leave the corporation to become an entrepreneur. New York: Harper and Rows

Pinchot, G., \& Pinchot, E. S. (2016). Intra-Corporate Entrepreneurship. Downloaded from: http://www.intrapreneur.com/MainPages/History/IntraCorp.html

Pirhadi, H., Feyzbakhsh, A. (2021). Corporate entrepreneurship, its antecedents, process, and consequences: A systematic review and suggestion for future research. Journal of International Entrepreneurship, 19, 196-222. doi:10.1007/s10843-021-00294-8

Poduska, Z., Nedelijkovic, J., Nonić, D., Ratknić, T., Ratnkić, M., Zivoijnović, I. (2020), Intrapreneurial climate as momentum for foresting employee innovativeness in public forest enterprises, Forest Policy and Economics 119, doi:10.1016/j.forpol.2020.102281

Prexel, KM. (2019). The intrapreneurship reactor: how to enable a start-up culture in corporations. $e$ \& $i$ Elektrotechnile und Informationstechnik, 136, 234-240. doi: 10.1007/s00502-019-0727-7

Rauch, J., Wiklund, G. T., Lumpkin, Frese M. (2009). Entrepreneurial orientation and business performance: An assessment of past research and suggestions for the future. Entrepreneurship. Theory and Practice, 33 (3), 761-787. doi:10.1111/j.1540-6520.2009.00308.x 
Schneider, B, Ehrhart, M. G., \& Macey, W. H. (2013). Organizational climate and culture. Annual Review of Psychology, 64, 361-388. doi: 10.1146/annurev-psych-113011-143809

Sharma, P., Chrisman, J. J. (1999). Toward a Reconciliation of the Definitional Issues in the Field of Corporate Entrepreneurship. Entrepreneurship. The Theory and Practice, 23 (3), 14-15. doi: 10.1177/104225879902300302

Sułkowski Ł. (2012). Kulturowe procesy zarzadzania. Warszawa: Wydaw. Difin

Smékalová, L., Hájek, O., Belás, J., \& Macháček, J. (2014). Perception of Small and Medium Entrepreneurship in the Czech Republic. Journal of Competitiveness, 6(4), 41-49. https://doi.org/10.7441/joc.2014.04.03

Szarucki, M. (2016). Model przedsiębiorczości strategicznej. Downloaded from: http:/ / nig.creatyvni.pl/index.php?option=com_content\&view=article\&id=113:model-przedsibiorczocistrategicznej\&catid=39:artykuly\&Itemid $=108$

Tastan, S. B., Gucel, C. (2014). Explaining intrapreneurial behaviors of employees with perceived organizational climate and testing the mediating role of organizational identyfication: A research study among employees of Turkish innovative firms, Procedia-Social and Behavioral Sciences, 150, 862-871. doi: 10.1016/j.sbspro.2014.09.095

Tseng, C., Tseng, C. C. (2019). Corporate entrepreneurship as a strategic approach for internal innovation performance. Asia Pacific Journal of Innovation and Entrepreneurship 13 (1), 108-120. doi: 10.1108/APJIE-08-2018-0047

Wiatrak, A. P. (2008). Przedsiębiorczość korporacyjna - istota, uwarunkowania i podstawowe obszary. Problemy Zarzadzania, 2 (20), 39-50

Wójcik-Karpacz, M. (2016). Orientacja przedsiębiorcza a sukces przedsiębiorstwa. Ustalenia literaturowe. Zarz̨qdzanie $i$ Finanse. Journal of Management and Finance, 14 (2/1), 483-496 